\title{
Fructose-Mediated Elevation of Hydrogen Production in Glucose Tolerant Mutant of Synechocystis Sp. Strain PCC 6803 under the Dark Anaerobic Nitrate-Free Condition
}

\author{
Adipa Chongsuksantikul*, Kazuhiro Asami, Shiro Yoshikawa and Kazuhisa Ohtaguchi \\ Department of Chemical Engineering, Tokyo Institute of Technology, Japan
}

\begin{abstract}
Fructose is a potential additive that elevates a supply of electrons to hydrogenase for hydrogen production in cyanobacteria. A series of dark anaerobic hydrogen production experiments was performed to evaluate the validity of this assumption, in which fructose from 0 to $110 \mathrm{mmol} / \mathrm{L}$ was added to HEPES buffer solution on which a glucose tolerant mutant of unicellular cyanobacterium Synechocystis sp. strain PCC 6803 (GT strain) was incubated. Despite the reported knowledge that fructose was an inhibitor for photoheterotrophic growth of Synechocystis cells, GT strain assimilated fructose and represented a limited heterotrophic growth on fructose in HEPES buffer solution under dark anaerobic condition. The initial hydrogen production rate that was $0.025 \mathrm{mmol} / \mathrm{L} \mathrm{h}$ in run without fructose increased to $0.0917 \mathrm{mmol} / \mathrm{L} \mathrm{h}$ in run with $60-83 \mathrm{mmol} / \mathrm{L}$ fructose. The associated increase in the initial amount of endogenous glucose from $0.22 \mathrm{mmol} / \mathrm{L}$ in run without fructose to $0.36 \mathrm{mmol} / \mathrm{L}$ in run with $50 \mathrm{mmol} / \mathrm{L}$ fructose was observed. Fructose released the complete suppression of hydrogen production by nitrate. This work presents the first experimental evidence that cells of GT strain are able to assimilate fructose for cell growth in dark anaerobic condition. Our results show that hydrogen production in Synechocystis sp. strain can be significantly elevated by a proper addition of fructose to dark anaerobic HEPES buffer solution.
\end{abstract}

Keywords: Dark; Fructose; Hydrogen; Lactate; NiFe-hydrogenase; Nitrate-free; Synecocystis sp. strain PCC 6803

\section{Introduction}

Cyanobacteria are capable of carbon dioxide fixation under the light, utilizing water as a primary electron donor, and generating free oxygen, ATP and low potential reductive compounds NADH, NADPH and $\mathrm{FADH}_{2}$ for metabolism. A number of cyanobacteria express an extremely oxygen-labile bidirectional $\mathrm{NiFe}$-hydrogenase activity that, under the absence of oxygen and highly reductive condition, serves to provide a terminal electron sink and reduce excess protons and NAD $(\mathrm{P})$ $\mathrm{H}$ by evolving hydrogen [1]. Stresses caused by the nitrate or sulfate limitations are effective to trigger hydrogen production in a unicellular non-nitrogen-fixing cyanobacterium Synechocystis sp. strain PCC 6803 $[2,3]$. Eliminating nitrate from medium constituents is established to be a key for dark hydrogen production, which is supported by an observation that a deletion mutant of the genes encoding both nitrate reductase and nitrite reductase significantly enhanced production [4]. Inhibitor addition to block of a certain electron sink pathway that is competitive to $\mathrm{NiFe}$-hydrogenase is applied to increase hydrogen production [5].

Fermentation of the endogenous glucose in the form of glycogen that is accumulated during photosynthesis is shown to be accompanied by the dark anaerobic hydrogen production in a unicellular cyanobacterium Gloeocapsa alpicola CALU 743 [6]. Dark anaerobic incubation of the glucose tolerant mutant of Synechocystis sp. strain PCC 6803 (hereafter GT strain) in the nitrate-free and glucose-supplemented HEPES (4-(2-hydroxyethyl)-1-piperazineethanesulfonic acid)) buffer solution results in an eminent increase in hydrogen production on bidirectional NiFe-hydrogenase [7]. Fructose is an isomer of glucose. Heterotrophic growth of the nitrogen-fixing filamentous cyanobacteria Anabaena species on fructose under the light and dark was previously reported [8], however, there are remarkably few data available on the dark heterotrophic growth and the dark hydrogen production of GT strain on fructose.
Fructose, along with glucose and sucrose, are three key sugars for photolithotrophs. Fructose is an extremely soluble ketohexose that exists in a cyclized form hemiacetal fructofuranose in solution. The fructofuranose has the anomeric carbon directly bonding to two oxygen atoms in the forms of a free $\mathrm{OH}$ group and an OR group. This anomeric carbon is susceptible to be oxidized via a redox reaction; hence ketohexose fructose is classified into a reducing sugar. If hydrogen production on NiFe-hydrogenase is the cellular response against redox unbalance, then a possibility exists that the presence of fructose in cellular environment affects hydrogen production [9].

Exogenous glucose and fructose are known to be transported through facilitated diffusion via a glucose-fructose permease (the product of the $g l c \mathrm{P}$ transport gene) [10]. Previous works show that Synechocystis sp. strain PCC6 714 transports glucose via permease with $K_{\mathrm{m}}$ of about $0.4 \mathrm{mmol} / \mathrm{L}[11]$ and fructose inhibits the uptake of glucose slightly [12]. The $K_{\mathrm{m}}$ for fructose consumption of Anabaena variabilis is reported to be approximately $0.16 \mathrm{mmol} / \mathrm{L}$ that does not change in the light versus dark [13]. Although sensing mechanism in GT strain for glucose is not defined, growth arrested cells are known to respond to glucose at the level of post-translational modifications or modulation of enzyme activities and phosphorylate the transported glucose to glucose 6-phosphate on glucokinase [14]. Glucose 6-phosohate is

*Corresponding author: Adipa Chongsuksantikul, Department of Chemical Engineering, Tokyo Institute of Technology, Tokyo 2-12-1 Ookayama, Meguro-Ku, Tokyo 152-8552, Japan, Tel: +81-3-5734-3034; E-mail: adipa.c.aa@m.titech.ac.jp

Received July 18, 2014; Accepted September 18, 2014; Published September 23, 2014

Citation: Chongsuksantikul A, Asami K, Yoshikawa S, Ohtaguchi K (2014) Fructose-Mediated Elevation of Hydrogen Production in Glucose Tolerant Mutan of Synechocystis Sp. Strain PCC 6803 under the Dark Anaerobic Nitrate-Free Condition. J Bioprocess Biotech 4: 175 doi: 10.4172/2155-9821.1000175

Copyright: (C) 2014 Chongsuksantikul A, et al. This is an open-access article distributed under the terms of the Creative Commons Attribution License, which permits unrestricted use, distribution, and reproduction in any medium, provided the original author and source are credited. 
Citation: Chongsuksantikul A, Asami K, Yoshikawa S, Ohtaguchi K (2014) Fructose-Mediated Elevation of Hydrogen Production in Glucose Tolerant Mutant of Synechocystis Sp. Strain PCC 6803 under the Dark Anaerobic Nitrate-Free Condition. J Bioprocess Biotech 4: 175 doi: 10.4172/2155-9821.1000175

Page 2 of 7

further decomposed mainly in the Oxidative Pentose Phosphate (OPP) pathway [15]. Fructose inhibits photoautotrophic growth of a culture of Synechocystis sp. strain PCC 6714 but, cannot result in a toxic effect on the chemoheterotrophic growth of the strain on $5 \mathrm{mmol} / \mathrm{L}$ glucose in the light [14]. Genome sequence of Synechocystis sp. strain PCC 6803 represents a potential-coding regions for fructokinase (Qry match, $18.4 \%$ ) in ORF slr1448 [16]. Glycogen accumulation in a heterocystous cyanobacterium Anabaena azollae is reported to be increased by fructose [17]. A recent work on higher plant Arabidopsis thaliana suggests that fructose is a signaling molecule regulating growth and development and that fructokinase plays a putative regulatory role in fructose signaling [18]. However fructose signal transaction pathway is yet unsolved.

In the present paper we report results of experiments which were designed to provide additional information on the fructose supported hydrogen production in Synechocystis sp. strain PCC 6803-GT under the dark anaerobic condition with or without nitrate.

\section{Materials and Methods}

\section{Strain, cell preparation and hydrogen production}

A glucose tolerant mutant of Synechocystis sp. strain PCC 6803 (hereafter GT strain) was supplied by Professor Y. Hihara, Department of Biochemistry and Molecular Biology, Saitama University, Japan. For cell preparation, cells were grown photoautotrophically for 3 days in BG-11 medium (initial $\mathrm{pH} 7.8$ ) at $34^{\circ} \mathrm{C}$, aerated by $6 \% \mathrm{CO}_{2}$ in air and illuminated by fluorescent lamps at $100 \mu \mathrm{mol}$ photons $/ \mathrm{m}^{2}$ photosynthetic photon flux density (PPFD). Utilizing the culture with $\mathrm{OD}_{730}$ at 3 , logarithmically growing cells were collected by centrifugation at $1000 \mathrm{~g}$ and $25^{\circ} \mathrm{C}$ for $10 \mathrm{~min}$. The cell pellets were first washed by $50 \mathrm{mmol} / \mathrm{L}$ HEPES buffer plus $18 \mathrm{mmol} / \mathrm{L} \mathrm{NaNO}_{3}$ and then washed again by pure HEPES (4-(2-hydroxyethyl)-1-piperazineethanesulfonic acid) buffer ( $\mathrm{pH}$ 7.8). The washed cells were collected by centrifugation. Cells were re-suspended and incubated in $10 \mathrm{~mL}$ of $50 \mathrm{mmol} / \mathrm{L}$ HEPES buffer ( $\mathrm{pH} 7.8$ ) solutions without or with $18 \mathrm{mmol} / \mathrm{L} \mathrm{NaNO}_{3}$, without or with $5,25,50,60,70$ and $110 \mathrm{mmol} / \mathrm{L}$ fructose and with $18 \mathrm{mmol} / \mathrm{L}$ $\mathrm{NaNO}_{3}$ plus $50 \mathrm{mmol} / \mathrm{L}$ fructose in $32 \mathrm{~mL}$ glass test tubes with butyl rubber caps. The initial dry cell weight concentration was set at $2 \mathrm{~g} / \mathrm{L}$ $\left(\mathrm{OD}_{730}=5.4\right)$ and cell suspension was purged with nitrogen gas for a few minutes to remove oxygen molecules. Incubation was carried out under the dark anaerobic conditions with shaking at $145 \mathrm{rpm}$ in a reciprocating shaker. The reciprocating distance was $40 \mathrm{~mm}$ and the horizontal angle was about $30^{\circ}$. Dark incubation in this study was slightly modified with a daily pulse of dim light. All experiments were carried out in duplicate.

\section{Measurement of hydrogen production}

The amount of molecular hydrogen in the gas phase of the closed $32 \mathrm{~mL}$ test tube was measured utilizing a gas chromatograph equipped with a molecular sieve column and a thermal conductivity detector (GC-320, GL science Inc.; column, Molecular sieve 13X; column temperature, $37^{\circ} \mathrm{C}$; injector temperature, $45^{\circ} \mathrm{C}$; detector temperature $80^{\circ} \mathrm{C}$ ) with nitrogen gas as the carrier gas.

\section{Measurement of fructose consumption and metabolic product production}

The amount of unreacted fructose in cell suspensions was analyzed by a high performance liquid chromatography (HPLC) (Shimadzu LC-10AD and RID-6A) with a $6.0 \phi \times 150 \mathrm{~mm}$ column SZ5532 (Showa Denko Co.). Column temperature was set at $50^{\circ} \mathrm{C}$. Mobile phase was
$70 \%$ acetonitrile. Mobile phase flow rate was $0.7 \mathrm{~mL} / \mathrm{min}$. A $10 \mu \mathrm{L}$ of supernatant sample was injected by using a $10 \mu \mathrm{L}$ syringe. Metabolites in supernatants were analyzed by HPLC (JASCO PU-2080 Plus and UV-2075 Plus). Mobile phase was $18 \mathrm{mmol} / \mathrm{L} \mathrm{KH}_{2} \mathrm{PO}_{4}, \mathrm{pH}$ of which was adjusted at 2.3 with $\mathrm{H}_{3} \mathrm{PO}_{4}$. Flow rate of mobile phase was $0.7 \mathrm{~mL} /$ min. Column temperature was $30^{\circ} \mathrm{C}$. A $10 \mu \mathrm{L}$ of supernatant sample was injected by using $10 \mu \mathrm{L}$ syringes. The wave length of $210 \mathrm{~nm}$ was used for analyzing lactate and acetate concentrations.

\section{Measurement of endogenous glucose accumulation and consumption}

For glucose analysis, defined dry weight cell pellets were collected by centrifugation of defined volume of cell suspension at $25^{\circ} \mathrm{C}, 3000$ rpm for $10 \mathrm{~min}$ and washing 3 times by deionized water to eliminate extracellular carbon sources. From defined amount of cell pellets, the endogenous glucose was obtained by extracting and decomposing glycogen with $50 \mu \mathrm{L}$ of $6 \mathrm{~N} \mathrm{HCl}$ at $80^{\circ} \mathrm{C}$ for $30 \mathrm{~min}$. The amount of endogenous glucose in glycogen per culture volume was determined by applying Glucose CII Test Wako (Wako Pure Chemical Ind., Ltd.). The almost $100 \%$ conversion of glycogen to glucose by this method is confirmed by employing glycogen assay kit containing amyloglucosidase on glycogen (data not shown).

\section{Measurement of dry cell weight}

The dry cell weight per culture volume was determined according to previous report [3].

\section{Results and Discussions}

Figure 1 compares the initial hydrogen production rates of dark anaerobically incubated cells of Synechocystis sp. strain PCC 6803GT in HEPES buffer solutions at different conditions. The number of moles of hydrogen per culture volume versus time data of those four runs gives linear relation in the first $48 \mathrm{~h}$ (data not shown), hence the initial hydrogen production rates are calculated by the amount of hydrogen per culture volume at $48 \mathrm{~h}$, divided by $48 \mathrm{~h}$. The hydrogen production data of the runs without fructose support the reported

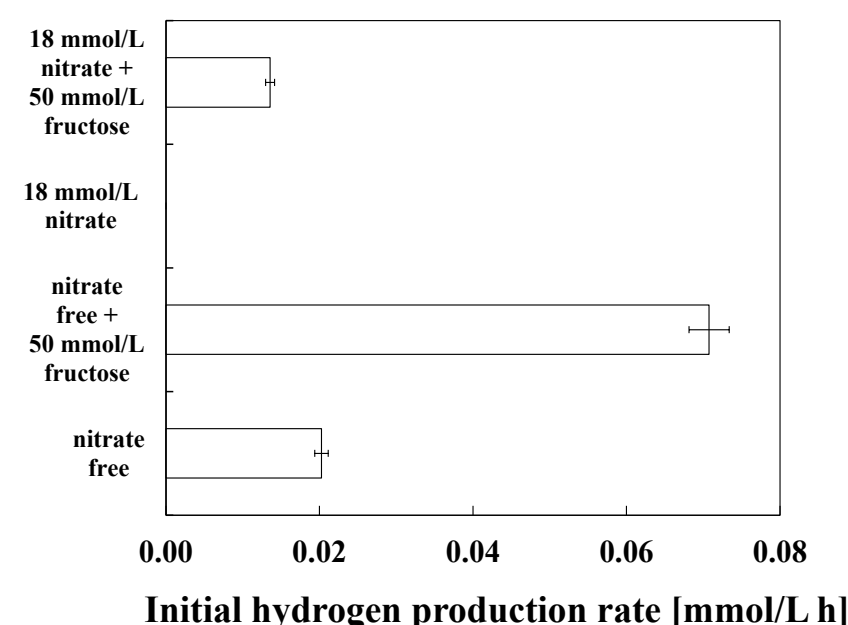

Figure 1: Effect of nitrate and fructose on the initial hydrogen production rate in Synechocystis sp. PCC 6803-GT. The hydrogen production was evaluated by the measurements of the amount of hydrogen per culture volume after 48 $h$ incubation of cells in HEPES buffer solutions (a) without nitrate or fructose, (b) without nitrate and with $50 \mathrm{mmol} / \mathrm{L}$ fructose, (c) with $18 \mathrm{mmol} / \mathrm{L} \mathrm{NaNO}$ and without fructose, and (d) with $50 \mathrm{mmol} / \mathrm{L}$ fructose and $18 \mathrm{mmol} / \mathrm{L} \mathrm{NaNO}_{3}$. All experiments were carried out in duplicate. 
Citation: Chongsuksantikul A, Asami K, Yoshikawa S, Ohtaguchi K (2014) Fructose-Mediated Elevation of Hydrogen Production in Glucose Tolerant Mutant of Synechocystis Sp. Strain PCC 6803 under the Dark Anaerobic Nitrate-Free Condition. J Bioprocess Biotech 4: 175 doi: 10.4172/2155-9821.1000175

Page 3 of 7

conclusion that hydrogen production is inhibited by nitrate because of the $\mathrm{NAD}(\mathrm{P}) \mathrm{H}$ competition between nitrate assimilation and hydrogen production [4]. The result of run without nitrate shows that fructose elevates dark anaerobic hydrogen productions in GT strain. The initial hydrogen production rate in run with fructose is 3.5 times that without fructose. The positive effect of fructose on the dark anaerobic hydrogen production is found to overcome the inhibitory effect of nitrate. This observation appears to be the first description on the dark anaerobic hydrogen production in GT strain in the presence of nitrate (Figure 1).

Figure 2 shows the time courses of the number of moles of hydrogen per culture volume $\left(y_{\mathrm{H} 2}\right)$. Hydrogen production starts right after inoculation, irrespective of varying $c_{\mathrm{s} 0}$. The time course of hydrogen production rate $\left(r_{\mathrm{H} 2}=\mathrm{d} y_{\mathrm{H} 2} / \mathrm{d} t\right)$ is studied. The initial hydrogen production rates $\left(r_{\mathrm{H} 20}\right)$ for runs with $c_{\mathrm{S} 0}$ at $0,5,25,50,60$ and $70 \mathrm{mmol} / \mathrm{L}$ are $0.025,0.031,0.059,0.091,0.093$ and $0.094 \mathrm{mmol} / \mathrm{L} \mathrm{h}$, respectively. The addition of $70 \mathrm{mmol} / \mathrm{L}$ fructose results in 3.7 -fold increase in the initial hydrogen production rate from run without fructose. The $48 \mathrm{~h}$ dark anaerobic incubation of Synechocystis cells in HEPES buffer solution without fructose and $\mathrm{N}$-deprivation condition in this work generated $0.927 \mu \mathrm{mol}$ hydrogen from (7) $\left(10^{9}\right)$ cells, which was acceptable when compared to $2.37 \mu \mathrm{mol}$ hydrogen from (7) $\left(10^{9}\right)$ cells shown in previous report $\left(\mathrm{OD}_{730}=0.1\right.$ equal to $(1.4)\left(10^{8}\right)$ cells/ $\mathrm{mL}$ ) [5]. This minor difference can be explained by the difference of temperature, gas phase composition and growth phase of Synechocstis cells. The $r_{\mathrm{H} 2}$ is not time-varied and same as the $r_{\mathrm{H} 20}$ at $0.0927 \mathrm{mmol} / \mathrm{L}$ $\mathrm{h}$ when $c_{\mathrm{S} 0}$ is no less than $50 \mathrm{mmol} / \mathrm{L}$. The $y_{\mathrm{H} 2}$ versus time data for runs with 50,60 and $70 \mathrm{mmol} / \mathrm{L}$ fructose are fitted by the relation:

$$
y_{H 2}=r_{H 2,0} t
$$

The straight broken line in Figure 2 fits well with observed values of runs with $c_{\mathrm{s} 0}$ at 50,60 and $70 \mathrm{mmol} / \mathrm{L}$. The number of moles of hydrogen per culture volume at $120 \mathrm{~h}$ of run without fructose was $11.1 \mathrm{mmol} / \mathrm{L}$. When fructose concentration was further increased, the observed $y_{\mathrm{H} 2}$ versus time data were fitted well with Equation (1) for runs with $c_{\mathrm{s} 0}$ at no more than $83 \mathrm{mmol} / \mathrm{L}$. The rate of hydrogen production in GT strain is found to be highest and extremely stable against the progress of hydrogen production when initial fructose concentration is set at between 50 and $83 \mathrm{mmol} / \mathrm{L}$. The upper limit of fructose concentration for the stable hydrogen production was observed at $110 \mathrm{mmol} / \mathrm{L}$, where cell weight concentration decreased with time and the initial hydrogen production rate dropped significantly (data not shown). This cell death represented that GT strain could not survive under the solution of high fructose concentration.

The $y_{\mathrm{H} 2}$ versus time data for run without fructose is fitted by the relation:

$$
y_{H 2}=\frac{r_{H 2,0}}{k}\{1-\exp (-k t)\}
$$

in which $k$ is the rate constant for the deactivation of hydrogen production. The smooth broken line in Figure 2 shows calculated $y_{\mathrm{H} 2}$ with the parameters $r_{\mathrm{H} 2}, 0.025 \mathrm{mmol} / \mathrm{L} \mathrm{h}$; and $k, 0.0151 \mathrm{l} / \mathrm{h}$, which shows a fairly good fit to observed $y_{\mathrm{H} 2}$. The $y_{\mathrm{H} 2}$ at $120 \mathrm{~h}$ of run without fructose is $1.7 \mathrm{mmol} / \mathrm{L}$. The hydrogen production with 50 $83 \mathrm{mmol} / \mathrm{L}$ fructose is found to be 6.54 times that without fructose. The long dashed short dashed line in Figure 2 is the calculated time course of $y_{\mathrm{H} 2}$ utilizing Equation (2) with the reference parameters $r_{\mathrm{H} 20^{2}}$, $0.0405 \mathrm{mmol} / \mathrm{L} \mathrm{h}$ and $k, 0.01861 / \mathrm{h}$, which were obtained from the results of experiments with late-logarithmically growing cells. [9]. The present observed $y_{\mathrm{H} 2}$ of run without fructose and with logarithmically growing cells is lower than that on the long dashed short dashed line.
The difference between broken lines (present work) and long dashed short dashed line (previous work) is highly suggestive of the inoculumgrowth-phase dependency of hydrogen production.

The result of run with $5 \mathrm{mmol} / \mathrm{L}$ fructose shows that effect of fructose is not obvious in the first $72 \mathrm{~h}$, while it becomes apparent after $72 \mathrm{~h}$. The $y_{\mathrm{H} 2}$ versus time data is on the curve of Equation (2) before 72 $\mathrm{h}$ and appears to approach to the straight line of Equation (1) after $72 \mathrm{~h}$. Interestingly, hydrogen production rate of runs with 5 and $25 \mathrm{mmol} / \mathrm{L}$ fructose became almost similar to that of runs with $50-70 \mathrm{mmol} / \mathrm{L}$ fructose.

The result of run with $25 \mathrm{mmol} / \mathrm{L}$ fructose shows that effect of fructose is obvious right after inoculation, however $r_{\mathrm{H} 2,0}$ of Equation (1) is lower than $0.0927 \mathrm{mmol} / \mathrm{L}$ that fits the result of run with $c_{\mathrm{s} 0}$ no less than $50 \mathrm{mmol} / \mathrm{L}$. After $72 \mathrm{~h}, r_{\mathrm{H} 2}$ of this run gradually increases with time.

Of greatest interest is the fructose-mediated activation and stabilization of hydrogen production after $72 \mathrm{~h}$. Fructose is found to elevate the number of moles of hydrogen per culture volume at $120 \mathrm{~h}$ by increasing the initial hydrogen production rate, and stabilizing it after $72 \mathrm{~h}$ (Figure 2).

To elucidate relations of hydrogen production to fructose utilization, acid evolution, endogenous glycogen metabolism and dry cell weight production, culture variables concerning these mechanisms are totally monitored. For runs with fructose, run with $25 \mathrm{mmol} / \mathrm{L}$ fructose is selected as a representative run because time courses of culture variables of runs with 5, 50, 60 and $70 \mathrm{mmol} / \mathrm{L}$ fructose qualitatively resembled those of run with $25 \mathrm{mmol} / \mathrm{L}$ fructose. Figure 3 compares the time courses of culture variables measured in run (a) without or (b) with $25 \mathrm{mmol} / \mathrm{L}$ fructose in nitrate-free HEPES buffer solutions under the dark anaerobic conditions. In the absence of fructose, lactate concentration was extremely low and reached only 0.2 $\mathrm{mmol} / \mathrm{L}$ at $120 \mathrm{~h}$, whereas, in the presence of fructose, lactate synthesis continuously occurred during $120 \mathrm{~h}$. The lactate production rate after $48 \mathrm{~h}$ was similar to the hydrogen production rate. The level of lactate concentration is seen to be the same order of magnitude of number of moles of hydrogen per culture volume. Increase in the lactate

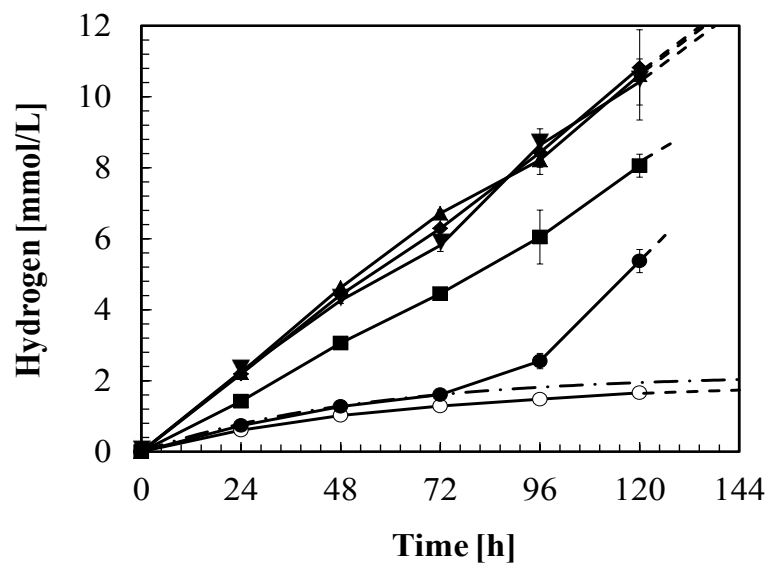

Figure 2: Time courses of number of moles of hydrogen per culture volume. Cells were incubated under the dark anaerobic condition in nitrate-free HEPES buffer solution supplemented with $0(\circ), 5(\bullet), 25(\bullet), 50(\bullet), 60(\boldsymbol{\Delta})$ or $70(\boldsymbol{\nabla}) \mathrm{mmol} / \mathrm{L}$ fructose. All experiments were carried out in duplicate. 
Citation: Chongsuksantikul A, Asami K, Yoshikawa S, Ohtaguchi K (2014) Fructose-Mediated Elevation of Hydrogen Production in Glucose Tolerant Mutant of Synechocystis Sp. Strain PCC 6803 under the Dark Anaerobic Nitrate-Free Condition. J Bioprocess Biotech 4: 175 doi: 10.4172/2155-9821.1000175

Page 4 of 7

concentration in the presence of fructose suggests that exogenous fructose is an additional carbon source for lactate production. The amount of intracellular lactate was not detectable level.

Different from lactate, acetate concentration rose to a maximum level at $72 \mathrm{~h}$ and then decreased. The highest concentration of acetate is $0.2 \mathrm{mmol} / \mathrm{L}$, hence the time course of acetate concentration is omitted from Figure 3 .

The time course data of dry cell weight concentration versus time of run without or with $25 \mathrm{mmol} / \mathrm{L}$ fructose shows that the dry cell weight concentration in run without fructose decreases slightly with time, whereas it in run with fructose slightly increases in the first $24 \mathrm{~h}$ and in the period between 72 and $120 \mathrm{~h}$. An interesting feature of Figure $3 \mathrm{~b}$ is a limited heterotrophic growth of GT strain on fructose under the dark anaerobic condition. This research is carried out to find the condition to elevate hydrogen production; hence cells were incubated not in BG11 medium but in HEPES buffer solution that contained only HEPES and $\mathrm{KOH}$ for $\mathrm{pH}$ adjustment. Fructose assimilation is seen in the first $24 \mathrm{~h}$ and in the final period between 72 and $120 \mathrm{~h}$. If $\left(-r_{\mathrm{s} 0}=-\mathrm{d} c_{\mathrm{s}} / \mathrm{d} t\right)$ is the initial fructose consumption rate, the $\left(-r_{\mathrm{SO}}\right)$ of run with $25 \mathrm{mmol} / \mathrm{L}$ fructose is $0.174 \mathrm{mmol} / \mathrm{L} \mathrm{h}$. A cessation of fructose assimilation is seen between 24 and $72 \mathrm{~h}$. The unreacted fructose concentration in this period is $23.9 \pm 0.56 \mathrm{mmol} / \mathrm{L}$. The combination of the curves for fructose concentration and dry cell weight concentration versus time in Figure $3 \mathrm{~b}$ eminently demonstrates the limited heterotrophic growth on fructose in the first $24 \mathrm{~h}$ and in the period between 72 and $120 \mathrm{~h}$.
This discontinuous heterotrophic growth on fructose suggests that GT strain appear to respond on cell cycle events to the initial shift of cellular environment to dark anaerobic condition with fructose.

The number of moles of endogenous glucose per culture volume of inoculum cells was fixed at $0.16 \mathrm{mmol} / \mathrm{L}$ by collecting the cells from the photoautotrophic culture of $\mathrm{OD}_{730}$ at 3 . The number of moles of endogenous glucose per culture volume for run without or with 25 $\mathrm{mmol} / \mathrm{L}$ fructose increased right after dark incubation, reached the maximum value at $24 \mathrm{~h}\left(c_{\mathrm{G}, \max }\right)$ of $0.22 \mathrm{mmol} / \mathrm{L}$ in run without fructose and $0.31 \mathrm{mmol} / \mathrm{L}$ in run with $25 \mathrm{mmol} / \mathrm{L}$ fructose, rapidly decreased from $24 \mathrm{~h}$ to $48 \mathrm{~h}$, and then approached to the stable level after $48 \mathrm{~h}$. The stable level observed at $120 \mathrm{~h}$ is higher in run with $25 \mathrm{mmol} / \mathrm{L}$ fructose than in run without fructose. The $c_{\mathrm{G} \text { max }}$ increases 1.40 -fold from run without fructose by adding $25 \mathrm{mmol} / \mathrm{L}$ fructose. For run without fructose, it is difficult to consider any carbon source for this glycogen synthesis other than endogenous carbonaceous compounds such as amino acids in protein, fatty acids in membrane lipid and derivatives of poly- $\beta$-hydroxybutyrate (PHB). Turnover of cell constituting materials is known to activate many $\mathrm{NAD}(\mathrm{P}) \mathrm{H}$-generating enzymes. If $r_{\mathrm{G} 0}$ and $r_{\mathrm{G} 0.0}$ are the initial rates of the accumulation of endogenous glucose and that in the absence of fructose, and if $r_{\mathrm{GS}, 0}$ is an increment of $r_{\mathrm{G} 0}$ from $r_{\mathrm{G} 0,0}$, then the experimental data of run with $25 \mathrm{mmol} / \mathrm{L}$ fructose results that $r_{\mathrm{G} 0}, r_{\mathrm{G} 0,0}$ and $r_{\mathrm{GS}, 0}$ are $0.00625,0.0025,0.00375 \mathrm{mmol} / \mathrm{L} \mathrm{h}$, respectively.

Glycogen in terms of endogenous glucose of runs without and
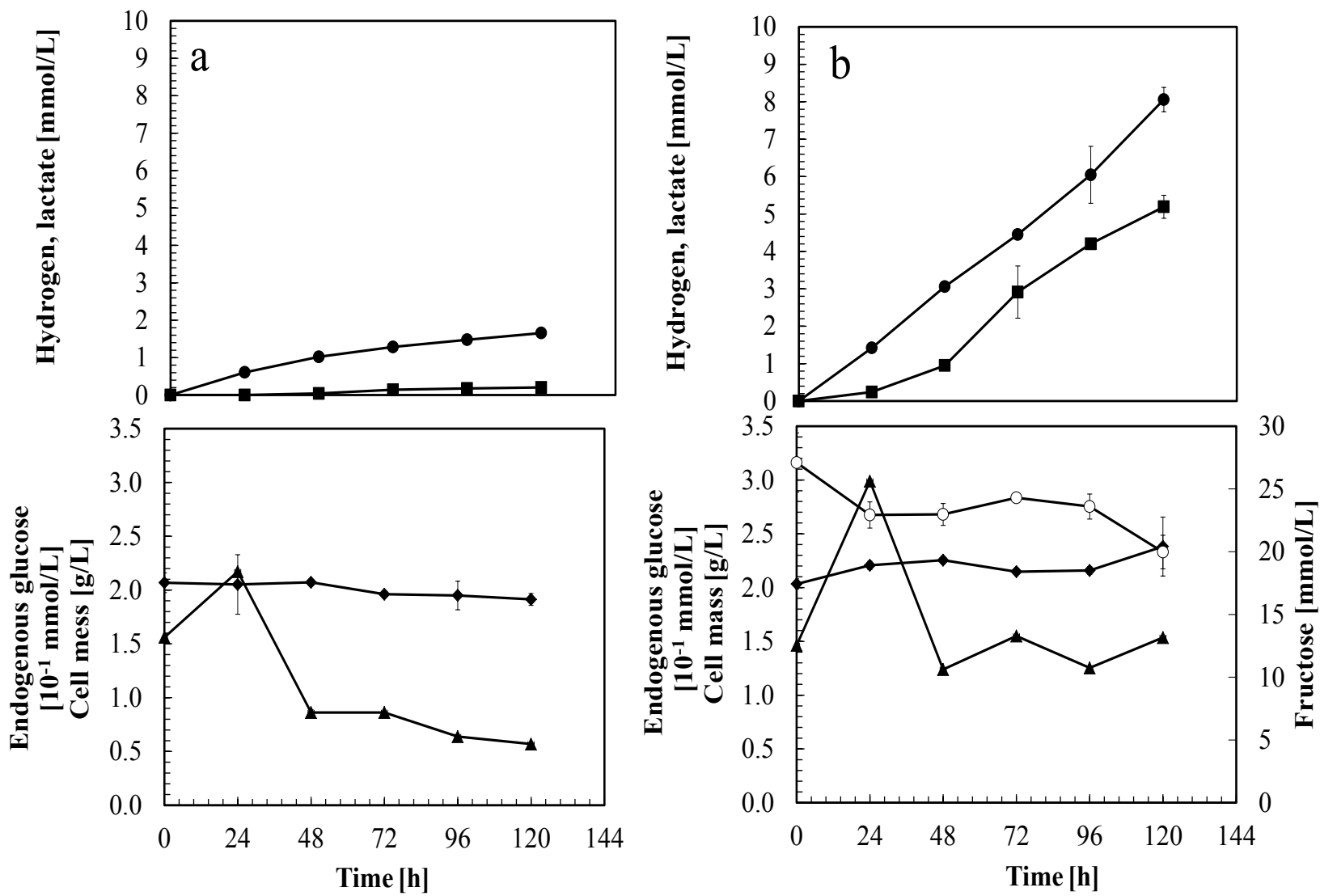

Figure 3: Time courses of the number of moles of hydrogen per culture volume $(\bullet)$, the concentrations of lactate $(\mathbf{\square})$, dry cell weight $(\bullet)$ and unreacted fructose $(\circ)$, and the number of moles of endogenous glucose per culture volume $(\boldsymbol{\Delta})$. Cells were incubated under the dark anaerobic nitrate-free HEPES buffer solutions supplemented without (a) or with $25 \mathrm{mmol} / \mathrm{L}$ fructose (b). All experiments were carried out in duplicate. 
Citation: Chongsuksantikul A, Asami K, Yoshikawa S, Ohtaguchi K (2014) Fructose-Mediated Elevation of Hydrogen Production in Glucose Tolerant Mutant of Synechocystis Sp. Strain PCC 6803 under the Dark Anaerobic Nitrate-Free Condition. J Bioprocess Biotech 4: 175 doi: 10.4172/2155-9821.1000175

Page 5 of 7

with $25 \mathrm{mmol} / \mathrm{L}$ fructose is drastically decomposed between 24 and 48 $\mathrm{h}$. This drop is from $0.22 \mathrm{mmol} / \mathrm{L}$ to $0.09 \mathrm{mmol} / \mathrm{L}$ in the run without fructose and from $0.31 \mathrm{mmol} / \mathrm{L}$ to $0.15 \mathrm{mmol} / \mathrm{L}$ in the run with 25 $\mathrm{mmol} / \mathrm{L}$ fructose. The assimilated amount of endogenous glucose per culture volume of run with fructose is comparable with that without fructose. Glycolysis is found to be independent from the presence of exogenous fructose and to proceed with the characteristic reaction rate of $0.00604 \mathrm{mmol} / \mathrm{L} \mathrm{h}$ and for the degradable glycogen amount of 0.145 $\mathrm{mmol} / \mathrm{L}$. When the degradable glycogen is assimilated, glycolysis is terminated.

Glycogen decomposition is known to generate NADH. The hydrogen production rate between $24 \mathrm{~h}$ and $48 \mathrm{~h}$ in run with 25 $\mathrm{mmol} / \mathrm{L}$ fructose is $0.0604 \mathrm{mmol} / \mathrm{L} \mathrm{h}$ that is 2.39 times that in run without fructose (Figure 2), hence the hydrogen production rate after $24 \mathrm{~h}$ is found to be independent from the amount of NADH generated by glycolysis. Considering that the amount of endogenous glucose per culture volume is increased by increasing initial fructose concentration and that the amount of assimilated endogenous glucose per culture volume after $24 \mathrm{~h}$ is not affected by initial fructose concentration, it is found that the amount of endogenous glucose per culture volume after $24 \mathrm{~h}$ is always higher in run with fructose than in run without fructose. Similar to the time course of the number of moles of endogenous glucose per culture volume, that per dry cell weight rises to a maximum at $24 \mathrm{~h}$ and then decreases (data not shown) (Figure 3).

Figure 4 shows the effect of change in initial fructose concentration on culture characteristic variables observed in runs without and with 5, 25, 50, 60 and $70 \mathrm{mmol} / \mathrm{L}$ fructose. Culture parameters states at $0 \mathrm{~h}$ and $120 \mathrm{~h}$ are shown by subscript 0 and 1 respectively. Fructose increased the initial hydrogen production rate and the total increase in number of molecules of hydrogen per culture volume (Figure 4a).

The plot of initial fructose consumption rate $\left(-r_{\mathrm{s} S}\right)$ versus initial fructose concentration $\left(c_{\mathrm{s} 0}\right)$ results the $K_{\mathrm{m}}$ for fructose consumption of $12.5 \mathrm{mmol} / \mathrm{L}$ and the maximum consumption rate $\left(-r_{\mathrm{s}}\right)_{\max }$ of 1.07 $\mathrm{mmol} / \mathrm{L} \mathrm{h}$. Broken line in Figure $4 \mathrm{~b}$ is the $\left(-r_{\mathrm{SO}}\right)$ calculated by the Michaelis-Menten kinetics, which fits well with observed consumption rate. The $K_{\mathrm{m}}$ of GT strain for fructose in HEPES buffer solution is found to be greater than that reported for Anabaena variabilis [13]. Low affinity of fructose to fructokinase in our experiment appears to be caused by limitation of ATP that is imperative for activation of fructokinase, since HEPES buffer solution lacks any phosphate ions.

The activated production of hydrogen in the presence of 50 $83 \mathrm{mmol} / \mathrm{L}$ fructose is found to be accompanied by the elevated assimilation of fructose (Figure $4 \mathrm{~b}$ ), the elevated initial synthesis of glycogen (Figure 4c), followed by the assimilation of endogenous glucose after $24 \mathrm{~h}$ and the elevated production of lactate (Figure $4 \mathrm{~d}$ ). Because of the insufficiency of required elements for normal cell growth, small portion of assimilated fructose is directed to cell growth (Figure 4b). When cells are exposed to fructose in buffer solution, the initial glycogen synthesis is activated, while the subsequent glycogen decomposition was not affected by initial concentration of fructose
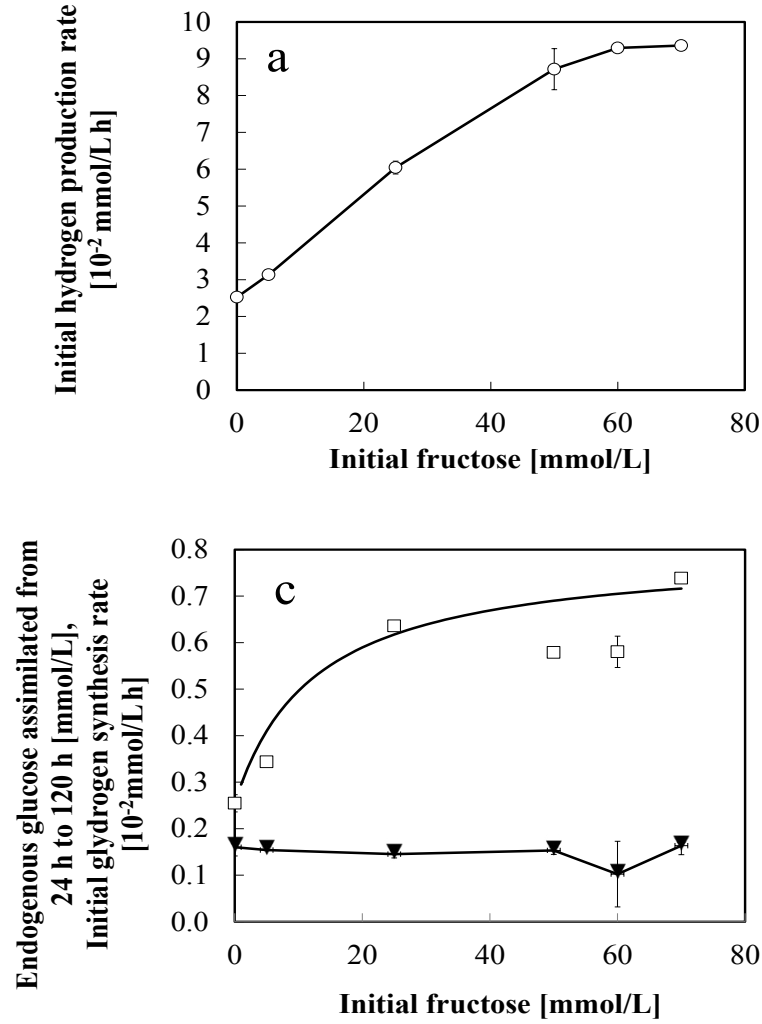
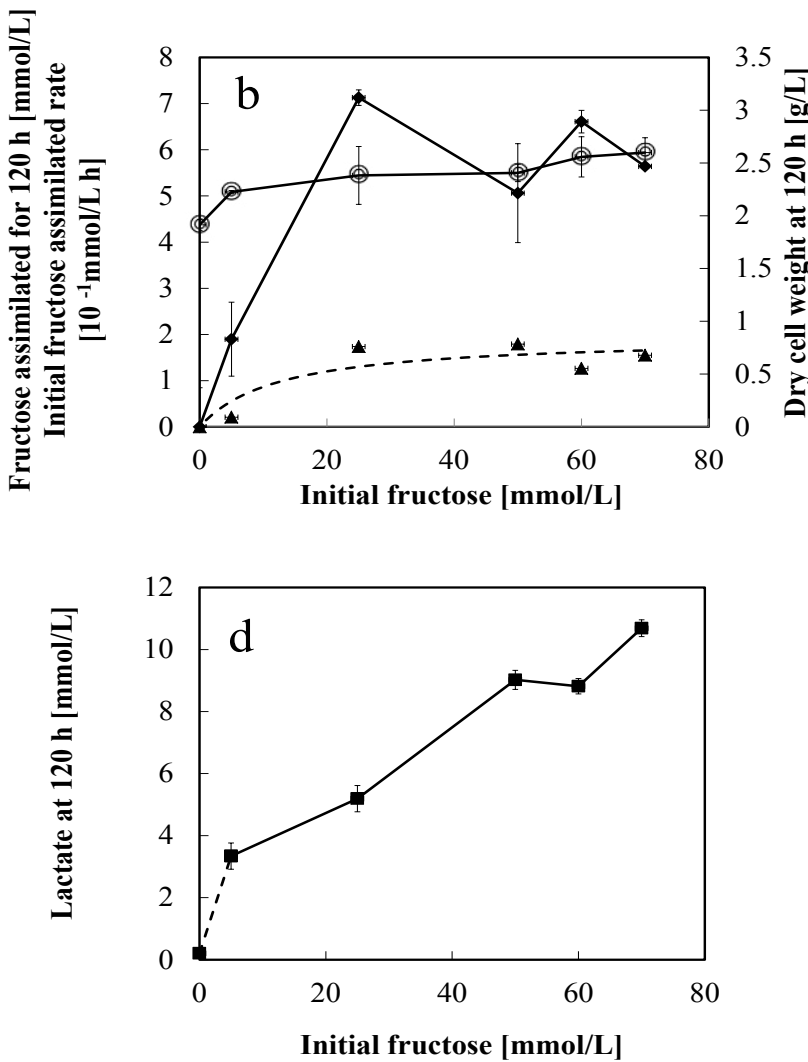

Figure 4: Relation between the initial fructose concentration and the characteristic variables of hydrogen production in Synechocystis sp. strain PCC 6803-GT under the dark anaerobic nitrate-free condition. Characteristic variables are the initial hydrogen production rate $(0)$, the number of moles of assimilated fructose per culture volume for $120 \mathrm{~h}(())$, the initial rate of fructose consumption that is observed from $0 \mathrm{~h}$ to $24 \mathrm{~h}(\mathbf{\Delta})$, the dry cell weight concentration at $120 \mathrm{~h}$ (@), the initial endogenous glucose accumulation rate $(\square)$, the number of moles of assimilated endogenous glucose per culture volume from 24 to $120 \mathrm{~h}(\boldsymbol{\nabla})$ and the lactate concentration at $120 \mathrm{~h}(\mathbf{\square})$. 
Citation: Chongsuksantikul A, Asami K, Yoshikawa S, Ohtaguchi K (2014) Fructose-Mediated Elevation of Hydrogen Production in Glucose Tolerant Mutant of Synechocystis Sp. Strain PCC 6803 under the Dark Anaerobic Nitrate-Free Condition. J Bioprocess Biotech 4: 175 doi: 10.4172/2155-9821.1000175

Page 6 of 7

(Figure 4c).

In the absence of fructose, endogenous glucose is synthesized in the first $24 \mathrm{~h}$ with the rate of $0.0025 \mathrm{mmol} / \mathrm{L} \mathrm{h}$ utilizing carbons from turnover mechanism, since the yield of endogenous glucose from fructose to endogenous glucose $\left(=r_{\mathrm{G} 0} /\left(-r_{\mathrm{S} 0}\right)\right)$ is calculated as $0.0279 \pm$ 0.0146 , which is quite low. Fructose is not mainly turned to endogenous glucose.

The time course of the number of moles of endogenous glucose per culture volume in Figure 3 shows that endogenous glucose consumed drastically between 24 and $48 \mathrm{~h}$. The assimilated amount of endogenous glucose from 24-120 h are not affected by initial fructose concentration, hence the amount of endogenous glucose per culture volume is found to be always higher in the presence of fructose than in the absence of fructose (Figure 4).

The number of moles of hydrogen per culture volume at $120 \mathrm{~h}$ is plotted against the number of moles of endogenous glucose per culture volume at $120 \mathrm{~h}$ in Figure 5a. The number of moles of hydrogen per culture volume at $120 \mathrm{~h}$ correlates well with the number of moles of endogenous glucose per culture volume at $120 \mathrm{~h}$. Figure $5 \mathrm{~b}$ also shows the relation between the $r_{\mathrm{G} 0}$ and the number of moles of hydrogen per culture volume at $120 \mathrm{~h}$. Good correlation is seen in this plot. To keep high level in the amount of endogenous glucose per culture volume appears to be of prime importance to result high hydrogen production in GT strain (Figure 5).

The assimilation of endogenous glucose is obvious between 24 $\mathrm{h}$ and $48 \mathrm{~h}$, hence the instantaneous fractional yield of hydrogen on endogenous glucose $Y_{\mathrm{H} 2 / \mathrm{G}}$ that is defined by the amount of hydrogen produced per amount of endogenous glucose utilized in this period is evaluated and plotted in Figure 6. Glucose 6-phosphate is an intermediate both in gluconeogenesis pathway and glycolysis pathway. If glucose 6-phosphate is catabolized in the Oxidative Pentose Phosphate (OPP) pathway and if both NADPH and ATP are required in this pathway, theoretical conversion of 1 mole glucose 6-phosphate to $5 / 3$ mole pyruvate is accompanied by the generation of 2 mole NADPH and $5 / 3$ mole NADH. When 1 mole pyruvate is completely converted to 3 mole carbon dioxide, this reaction yields 4 mole NADH and 1 mole $\mathrm{FADH}_{2}$. If all of $\mathrm{NAD}(\mathrm{P}) \mathrm{H}$ generated in these pathways are directed to NiFe-hydrogenase, potential yields of hydrogen in the pathway from glucose 6-phosphate to pyruvate and from glucose 6-phosphae to carbon dioxide are estimated as 3.67 and 12, respectively. The yield of hydrogen for run without fructose in Figure 6 is slightly lower than the theoretical yield from glucose 6-phosphate to pyruvate and that for runs with $50-70 \mathrm{mmol} / \mathrm{L}$ fructose is much higher than the theoretical yield from glucose-6-phosphate to carbon dioxide. Our observation suggests that $\mathrm{NAD}(\mathrm{P}) \mathrm{H}$ for hydrogen production are supplied not only from glycogen degradation but also from turnover of proteins, membrane lipid and PHB. This turnover appears to be accompanied by glycolysis. The observed lactate level was high at high initial fructose concentration. High concentration fructose appears to activate $\mathrm{NiFe}$ hydrogenase and lactate dehydrogenase to discharge excess reductants generated in the incomplete tricarboxylic acid (TCA) cycle [13] and in the pathways for turnover of above components.

Two additional experiments were done in which GT strain was added to the dark anaerobic HEPES buffer solution supplemented with $5 \mathrm{mmol} / \mathrm{L} \mathrm{FeCl}_{2}$ and that with $5 \mathrm{mmol} / \mathrm{L}$ ascorbic acid, in order to observe if the exposure of cells to reductive compounds is related to hydrogen production. When autoclaved, $\mathrm{Fe}^{2+}$ (green) solution turned to $\mathrm{Fe}^{3+}$ (red brown) due to unstable form of $\mathrm{Fe}^{2+}$. There were
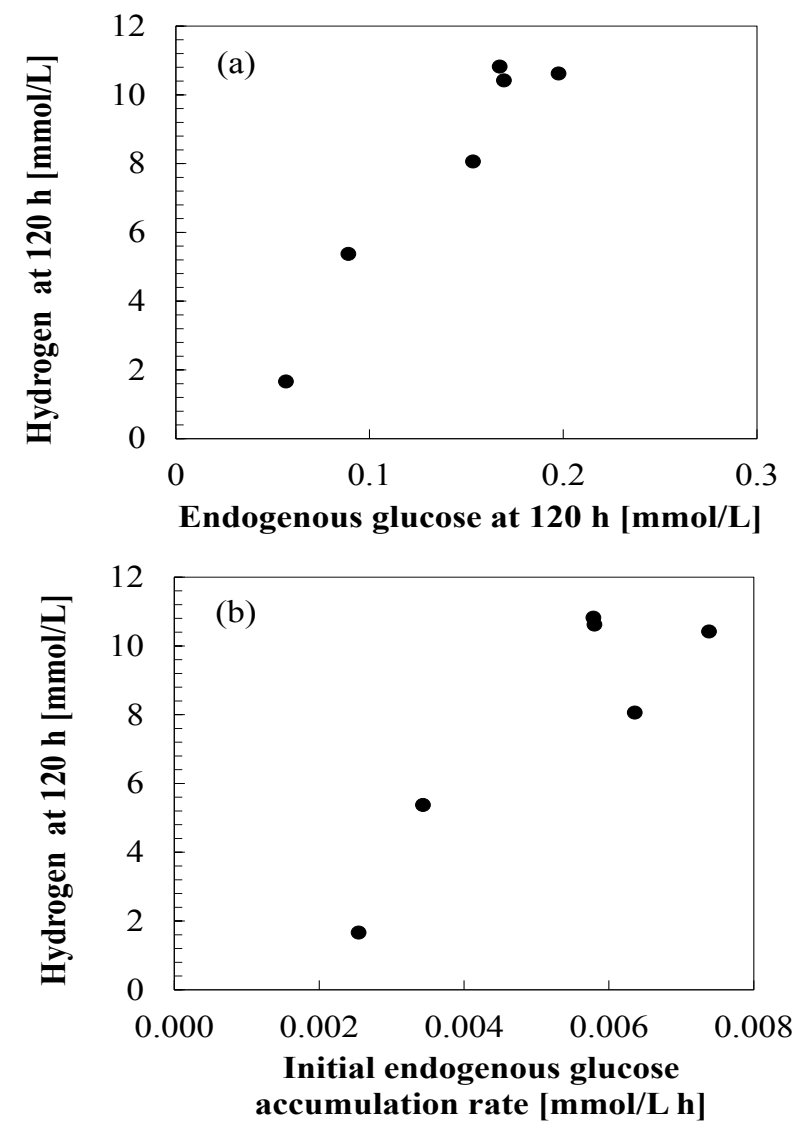

Figure 5: Relation between the number of moles of hydrogen per culture volume at $120 \mathrm{~h}$ versus (a) endogenous glucose at $120 \mathrm{~h}$ and (b) the initial endogenous glucose accumulation rate. $R^{2}$ were 0.93 and 0.79 for (a) and (b), respectively.

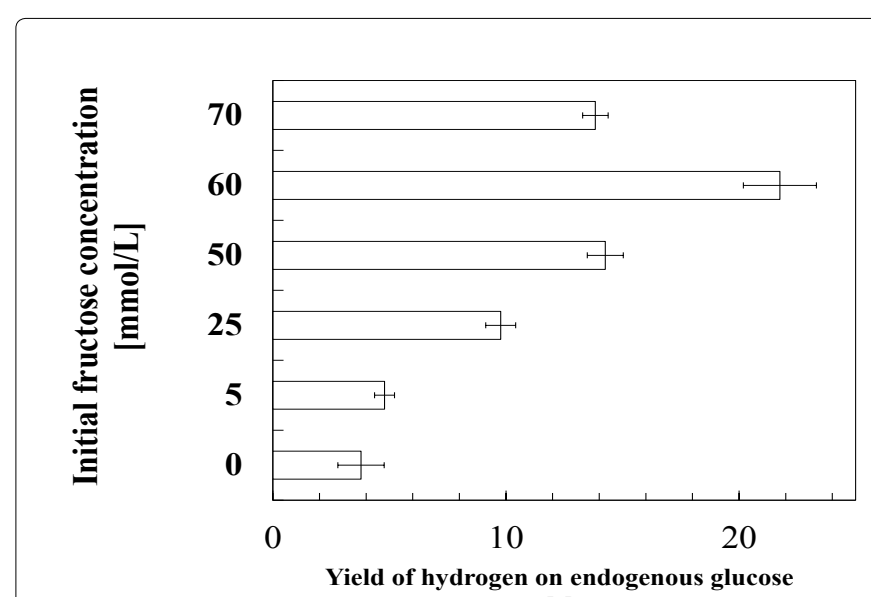

[-]

Figure 6: Relation between initial concentration of fructose and yield of hydrogen on endogenous glucose in the period between $24 \mathrm{~h}$ and $48 \mathrm{~h}$.

no improvements of hydrogen production in the presence of those reductive compounds (data not shown). The positive effect of fructose on hydrogen production in our result suggests that fructose transport through cellular membrane is of prime importance to elevate hydrogen 
Citation: Chongsuksantikul A, Asami K, Yoshikawa S, Ohtaguchi K (2014) Fructose-Mediated Elevation of Hydrogen Production in Glucose Tolerant Mutant of Synechocystis Sp. Strain PCC 6803 under the Dark Anaerobic Nitrate-Free Condition. J Bioprocess Biotech 4: 175 doi: 10.4172/2155-9821.1000175

production.

Previously, we reported the elevation of dark anaerobic production of hydrogen in GT strain by adding glucose in HEPES buffer solution [7]. Hydrogen production in cells under glucose fermentation is different from that in fructose fermentation because cells extensively utilize glucose for cell division and thus, more cell population results in more hydrogen production (data not shown). In fructose under dark anaerobic condition, cells utilize fructose for endogenous glucose buildup rather than limited cell growth. This endogenous glucose accumulation is followed by the endogenous glucose break down by glycolysis that triggers many intracellular associated turnover reactions against cell constituting components. Cells gain more electrons through glycolysis and associated turnover reactions. This is partially supported by the increase in lactate concentration in runs with fructose since lactate is one of key carbon terminal compounds. Since fructose inhibited photoheterotrophic growth, our observation suggests that fructose might suppress an important pathway or mechanism related to light mode of life. Interestingly, this growth inhibition was not observed under dark anaerobic mode of life. Suppression of specific mechanism by fructose might be a key for redirection of more electrons to hydrogenase enzyme (Figure 6).

\section{Conclusions}

This work has demonstrated that fructose is a carbon source for a heterotrophic growth of a glucose tolerant mutant of cyanobacterium Synechocystis sp. strain PCC 6803 in the dark anaerobic HEPES buffer solution. Growth was observed but limited because only HEPES buffer with fructose was utilized as a medium. This observation differs from previous works that showed that fructose inhibited photoheterotrophic cell growth. Right after dark incubation, cells consumed fructose for endogenous glucose accumulation and dry cell weight production. Affinity to fructose was extremely low. At the end of dark incubation, the number of moles of endogenous glucose per culture volume correlates well with the number of moles of hydrogen per culture volume. To increase hydrogen production, a shift-up of the number of moles of endogenous glucose per culture volume is found to be of utmost importance. Our result shows that addition of fructose into HEPES buffer solution is effective to increase the number of moles of endogenous glucose per culture volume. Further experiments are necessary before the roles of fructose and endogenous glucose for hydrogen production are known.

\section{References}

1. Ducat DC, Sachdeva G, Silver PA (2011) Rewiring hydrogenase-dependent redox circuits in cyanobacteria. Proc Natl Acad Sci U S A 108: 3941-3946.

2. Antal TK, Oliveira P, Lindblad $P(2006)$ The bidirectional hydrogenase in the cyanobacterium Synechocystis sp. strain PCC 6803. International Journal of Hydrogen Energy 31: 1439-1444.

3. Yamamoto T, Asami K, Ohtaguchi K (2012) Anaerobic production of hydrogen in the dark by Synechocystis sp. strain PCC6803: effect of photosynthesis media for cell preparation. J Biochem Tech 3: 344-348.
4. Baebprasert W, Jantaro S, Khetkorn W, Lindblad P, Incharoensakdi A (2011) Increased $\mathrm{H}_{2}$ production in the cyanobacterium Synechocystis sp. strain PCC 6803 by redirecting the electron supply via genetic engineering of the nitrate assimilation pathway. Metab Eng 13: 610-616.

5. Burrows EH, Chaplen FW, Ely RL (2011) Effects of selected electron transport chain inhibitors on 24-h hydrogen production by Synechocystis sp. PCC 6803. Bioresour Technol 102: 3062-3070.

6. Troshina O, Serebryakova L, Sheremetieva M, Lindblad P (2002) Production of $\mathrm{H}_{2}$ by the unicellular cyanobacterium Gloeocapsa alpicola CALU 743 during fermentation. International Journal of Hydrogen Energy 27: 1283-1289.

7. Yamamoto T, Chongsuksantikul A, Asami K, Ohtaguchi K (2012) Anaerobic production of hydrogen in the dark by Synechocystis sp. strain PCC 6803 supplemented with D-glucose. J Biochem Tech 4: 464-468.

8. Ungerer JL, Pratte BS, Thiel T (2008) Regulation of fructose transport and its effect on fructose toxicity in Anabaena spp. J Bacteriol 190: 8115-8125.

9. Chongsuksantikul A, Asami K, Yoshikawa S, Ohtaguchi K (2014) Hydrogen production by anaerobic dark metabolism in Synechocystis sp. strain PCC6803GT: effect of monosaccharide in nitrate free solution. J Biochem Tech 5: 685-692.

10. Joset F, Buehou T, Zhang CC, Jeanjean R (1988) Physiological and genetic analysis of the glucose-fructose permeation system in two Synechocystis species. Archives of Microbiology 149: 417-421.

11. Beauclerk AA, Smith AJ (1978) Transport of D-glucose and 3-O-methyl-Dglucose in the cyanobacteria Aphanocapsa 6714 and Nostoc strain Mac. Eur J Biochem 82: 187-197.

12. Flores E, Schmetterer G (1986) Interaction of fructose with the glucose permease of the cyanobacterium Synechocystis sp. strain PCC 6803. J Bacteriol 166: 693-696

13. Haury JF, Spiller H (1981) Fructose uptake and influence on growth of and nitrogen fixation by Anabaena variabilis. J Bacteriol 147: 227-235.

14. Kahlon S, Beeri K, Ohkawa H, Hihara Y, Murik O, et al. (2006) A putative senso kinase, Hik31, is involved in the response of Synechocystis sp. strain PCC 6803 to the presence of glucose. Microbiology 152: 647-655.

15. Ungerer JL, Pratte BS, Thiel T (2008) Regulation of fructose transport and its effect on fructose toxicity in Anabaena spp. J Bacteriol 190: 8115-8125.

16. Kaneko T, Sato S, Kotani H, Tanaka A, Asamizu E, et al. (1996) Sequence analysis of the genome of the unicellular cyanobacterium Synechocystis sp. strain PCC6803. II. Sequence determination of the entire genome and assignment of potential protein-coding regions (supplement). DNA Res 3: 185-209.

17. Rozen A, Arad H, Schonfeld M, Tel-Or E (1986) Fructose supports glycogen accumulation, heterocysts differentiation, N2 fixation and growth of the isolated cyanobiont Anabaena azollae. Archives of Microbiology 145: 187-190.

18. Cho YH, Yoo SD (2011) Signaling role of fructose mediated by FINS1/FBP in Arabidopsis thaliana. PLoS Genet 7: e1001263.

19. Zhang S, Bryant DA (2011) The tricarboxylic acid cycle in cyanobacteria Science 334: 1551-1553.t 